\title{
Identifikasi Dan Keanekaragaman Jenis Jamur Ektomikoriza Pada Hutan Jati Di Seram Bagian Timur
}

\author{
Halima Kasongat ${ }^{1}$, Muzna A.A. Gafur ${ }^{2}$ Ponisri $^{3}$ \\ ${ }^{1}$ Universitas Muhammadiyah Sorong \\ HalimaKasongat09@gmail.com \\ ${ }^{2}$ Universitas Muhammadiyah Sorong \\ muznagafur@gmail.com \\ ${ }^{3}$ Universitas Muhammadiyah Sorong \\ poai.sri1006@gmail.com
}

\begin{abstract}
Abstrak
Penelitian ini bertujuan untuk mengidentifikasi, keanekaragaman, kemerataan dan dominas dan habitat dari jenis-jenis jamur ektomikoriza yang tumbuh di wilayah hutan jati Seram Bagian Timur. Metode yang digunakan adalah metode observasi/pengamatan langsung di lapangan. Untuk pengambilan data jamur ektomikoriza dibuat plot secara purposive sebanyak 15 plot pengamatan dengan ukuran plot $20 \times 20 \mathrm{~m}$, sehingga luas keseluruhan areal penelitian $6000 \mathrm{~m} 2(0,6 \mathrm{ha})$ dari luas keseluruhan hutan jati $7500 \mathrm{~m} 2$ $(0,75$ ha). Berdasarkan hasil penelitian di lapangan tentang Identifikasi dan Keanekaragaman Jenis Jamur Ektomikoriza Pada Hutan Jati di Seram Bagian Timur adalah sebagai berikut jenis jamur ektomikoriza yang terdapat pada tegakan hutan jati di Kampung Wailola di Seram Bagian Timur ditemukan 10 famili dengan 16 jenis jamur ektomikoriza dan jumlah seluruhnya ada 203 individu dimana jenis terbanyak adalah dari famili Polyporaceae ada tiga jenis, kedua dari famili Ganodermataceae, Strophariaceae, Agaricaceae, dan Amanitaceae masing-masing 2 jenis dan selanjutnya dari family Auriculariaceae, Pyronemateceae, Physacriaceae, Schizophyllaceae, dan Cortinariaceae masing-masing 1 jenis. Nilai indeks keanekaragaman dan kemerataan jenis ektomikoriza pada tegakan hutan jati adalah tinggi. Untuk nilai keanekaragaman jenis adalah 1,2625 dan indeks kemerataan jenis yaitu 1,0485. Sedangkan nilai indeks dominasi jenis ektomikoriza pada tegakan hutan jati adalah rendah $(0,1077)$. Habitat jamur ektomikoriza pada tegakan hutan jati yaitu saprofit dan epifit. Saprofit mempunyai jumlah jenis dan presentase yang lebih tinggi sebanyak 13 jenis $(81,25 \%)$ dan habitat epifit 3 jenis $(18,75 \%)$.
\end{abstract}

Kata Kunci: Identifikasi, Keanekaragaman, Jamur Ektomikoriza, Hutan Jati.

\section{PENDAHULUAN}

Jamur atau mikoriza adalah jenis tumbuhan tingkat rendah tanpa klorofil, tidak mempunyai perbedaan batang, daun dan akar (tidak mempunyai diferensiasi/thallophyte), tubuhnya terdiri atas satu sel atau lebih berupa benang-benang bercabang (hifa atau miselium), hifa dapat bercabang-cabang ke semua arah, selnya ada yang bersekat dan ada yang tidak, tiap sel berinti satu atau lebih, hidup secara saprofit 


\section{Median Volume 11 Nomor 1 Bulan Februari 2019}

Doi http://doi.org/md.v11i1.461

dan atau parasit, berkembang biak dengan cara aseksual (Dwidjoseputro, 2003).

Jamur mikoriza struktur yang di bentuk dalam asosiasi jamur ini disusun beraturan dan spktrumnya sangat luas baik tanaman inang jenis jamur maupun penyebarannya. Nuhamara (2009) menyatakan bahwa jamur mikoriza memiliki struktur khas karena adanya hubungan fungsional saling menguntungkan antara suatu jenis tumbuhan tertentu dengan satu atau beberapa galur mikobion dalam ruang dan waktu. Mikoriza berperan penting dalam dekomposisi bahan organik di alam selain dimanfaatkan oleh manusia untuk bahan baku obat karena mengandung banyak vitamin, meneral dan elemen mikro serta zat-zat penting untuk mencegah atau mengatasi beberapa jenis penyakit (Gandjar dkk.,2006).

Mikoriza merupakan struktur yang dibentuk oleh simbiosis antara akar tumbuhan tingkat tinggi dengan jamur. Mikoriza berperan membantu tumbuhan dalam meningkatkan penyerapan air, nitrogen dan fosfor serta unsur hara lainnya dalam tanah. Selain itu meningkatkan pertumbuhan inang dan memperpanjang umur akar sehingga tanaman dapat bertahan hidup, meningkatkan resistensi terhadap kekurangan air dalam tanah, temperatur tanah yang tinggi dan racun-racun tanah serta mencegah serangan patogen akar (Jülich, 1988 dalam Amisah, 2012).

Mikoriza terdiri dari endomikoriza, ektomikoriza dan ektendomikoriza, ketiga tipe tersebut merupakan ektomikoriza yang memiliki jumlah jenis jamur paling banyak miselium jamur yang menyelubungi permukaan akar di dalam dinding korteks (interselluler) akar tumbuhan yang membentuk jaringan hartig (Diagne et al., 2013; Dighton, 2016).

Terkait dengan keberadaannya, jamur ektomikoriza merupakan suatu tolok ukur yang terhadap kondisi hutan alam yang telah di konservasi maupun dalam bentuk konservasi lain kondisinya akan menjadi tidak sesuai dengan kondisi jenis jamur ektomikoriza, hal ini terutama karena perubahan iklim mikro di bawah tegakan dan tajuk serta inang yang tidak sesuai tumbuhan dengan asosiasi jamur ektomikoriza yang mendominasi ekosistem hutan alam tropis campuran, sehingga jamur ektomikoriza dapat banyak ditemukan pada jenis tanah (Brealey, 2006 ). Menurut Mardji, dkk ( 1999), setidaknnya ada 60 jenis jamur ektomikoriza di berada wilayah Kalimantan Timur (Bukit Soeharto) dimana sebagian hutannya berupa hutan sekunder di dominasi oleh jenis pohon dipterokarpa berukuran besar. lebih lanjut Noor (2010), di daerah Labanan Berau dan Kecamatan Muara Wahau ditemukan jenis jamur ektomikoriza kurang lebih $28,2 \%$, ada 27 genus dan 257 individu yang bersimbiosis dengan beberapa jenus pohon terutama dari famili Dipterocarpaceae, Leguminosae, Annonaceae, Sapotaceae, Fagaceae, dan Myristicaceae. Beberapa hasil penelitian pada jenis tanaman yang berbeda menemukan adanya beberapa jenis mikoriza, seperti yang dilakukan oleh Warrouw dan Kainde (2010) dalam Kandari, dkk (2016) yang menemukan tiga jenis spora yaitu Glomus, Gigaspora, Sclerocystis dan Acaulospora pada pohon jati. Cendawan ektomikoriza penggunaannya masih sangat terbatas, yaitu hanya dijumpai dan digunakan pada tumbuhan tingkat tinggi seperti pada pohon kehutanan tertentu yang diperlukan sekali guna meningkatkan pertumbuhannya (Setiadi, 1998 dalam Darwo dan Sugiarti, 2008).

Manfaat asosiasi ektomikoriza dengan tanaman jati sangat penting yaitu untuk membantu akar tanaman dalam penyerapan unsur hara makro dan mikro terutama fosfat (meknismenya terjadi peningkatan permukaan absorbsi, kerja pada enzim fofatase dan enzim oksalat). Selain itu meningkatkan ketahanan tanaman terhadap kekeringan, 


\section{Median Volume 11 Nomor 1 Bulan Februari 2019}

menghambat pertumbuhan pathogen akar (mekanisme; memperbaiki nutrisi tanaman , lapisan hifa yang menutupi akar akan melepaskan antibiotic) (Husna dkk, 2007). Melihat peranan yang sangat penting jamur ektomikoriza terhadap pertumbuhan pohon jati maka perlu dilakukan penelitian untuk mengidentifikasi jenis-jenis jamur ektomikoriza, dan mengetahui keanekaragaman, kemerataan, dominasi dan habitat jenis ektomikoriza jamur yang tumbuh di wilayah hutan jati Seram Bagian Timur.

\section{METODOLOGI PENELITIAN}

\section{Tempat dan Waktu Penelitian}

Penelitian ini dilaksanakan di kawasan hutan jati Kampung Wailola Kecamatan Bula Seram Bagian Timur dengan waktu pelaksanaan penelitian kurang lebih 1 bulan yaitu mulai bulan Agustus sampai dengan September 2018.

\section{Bahan dan Alat Penelitian}

Bahan yang menjadi objek penelitian yaitu jenis-jenis jamur ektomikoriza dan habitatnya pada pohon jati. Sedangkan alat yang digunakan dalam penelitian ini adalah Peta kerja, Meteran (100 / 50 m), Penggaris, Caliper mini atau jangka sorong, Kamera foto, Label dan kantong plastic, Cool box dan Buku pengenal jenis jamur serta tabel lapangan/tally sheet

\section{Metode Penelitian}

Metode yang digunakan adalah metode observasi/pengamatan langsung di lapangan. Untuk pengambilan data jamur ektomikoriza dibuat plot secara purposive sebanyak 15 plot pengamatan dengan ukuran plot 20 x $20 \mathrm{~m}$, sehingga luas keseluruhan areal penelitian $6000 \mathrm{~m} 2$ (0,6 ha) dari luas keseluruhan hutan jati $7500 \mathrm{~m} 2$ (0,75 ha). Pengamatan jamur ektomikoriza pada semua plot yang dibuat dengan ukuran berdasarkan tingkat penyebaran jamur ektomikoriza tersebut pada hutan jati Seram Bagian Timur. Pengamatan terhadap jamur ektomikoriza terdiri dari jenis-jenis, keanekaragam, kemerataan, dominansi dan habibtat tumbuhnya jamur .

\section{Analisis Data}

Data hasil observasi lapangan dianalisis secara deskriptif kualitatif dan kuantitatif serta disajikan dalam bentuk tabel dan gambar. Untuk menentukan

\section{Keanekaragaman Jenis Jamur Ektomikoriza}

Digunakan indeks keanekaragaman jenis $(\mathrm{H})$ dari Shanon dan Wiener menurut Odum (1993) dalam Indriyanto (2006) sebagai berikut:

$$
H=-\sum\left[\frac{n i}{N}\right] \cdot \log \left[\frac{n i}{N}\right]
$$

Keterangan:

$H=$ Indeks keanekaragaman

$n i=$ Jumlah spesies ke-i

$N=$ Jumlah seluruh spesies

Keanekaragaman jenis merupakan ciri tingkatan komunitas berdasarkan organisasi biologinya. Keanekaragaman jenis dapat digunakan untuk menyatakan struktur komunitas juga stabilitas komunitas yaitu kemampuan suatu komunitas agar dapat menjaga dirinya tetap stabil meskipun ada gangguan terhadap komponenkomponennya (Soegianto, 1994). Keanekaragaman jenis yang tinggi akan menunjukkan 


\section{Median Volume 11 Nomor 1 Bulan Februari 2019}

bahwa suatu komunitas memiliki kompleksitas tinggi karena interaksi jenis yang terjadi dalam komunitas itu sangat tinggi. Suatu komunitas dapat memiliki keanekaragaman jenis yang tinggi jika komunitas itu disusun oleh banyak jenis. Sebaliknya suatu komunitas akan memiliki keanekaragaman jenis yang rendah jika komunitas itu disusun oleh sedikit jenis dan jika ada jenis yang dominan (Indriyanto, 2006).

\section{Kemerataan Jenis Jamur ektomikoriza}

Untuk kemerataan jenis jamur ektomikoriza pada jalur penelitian, dilakukan analisis yang menggunakan indeks kemerataan jenis (e) menurut Odum (1993) dalam Indriyanto (2006) sebagai berikut:

$$
e=\frac{H}{\log S}
$$

Keterangan:

$e=$ Indeks kemerataan

$H=$ Indeks keanekaragaman jenis

$S=$ Jumlah seluruh jenis yang ada

Analisis juga dilakukan secara tabulasi untuk mengetahui keberadaan jenis jamur ektomikoriza di dalam jalur pengamatan. Besarnya nilai persentase adalah hasil dari perbandingan antara jumlah jalur ditemukannya jenis jamur ektomikoriza dengan jumlah seluruh jalur pengamatan. Dengan menggunakan jumlah individu yang diperoleh untuk menggambarkan suatu kemerataan jenis jamur ektomikoriza.

\section{Dominasi Jenis}

Untuk menentukan keberadaan jenis jamur ektomikoriza yang menyatakan tingkat penguasaan jenis dalam suatu komunitas digunakan rumus Indeks Dominasi Jenis (C) dari Simpson (1949) dalam Odum (1993) dalam Indriyanto (2006) sebagai berikut:

$$
C=\sum\left[\frac{n i}{N}\right]^{2}
$$

Keterangan:

$C=$ Indeks dominasi

$n i=$ Jumlah individu jenis ke-i

$N=$ Jumlah individu seluruh jenis

Dominasi merupakan sifat komunitas yang memperlihatkan suatu jumlah jenis organisme yang melimpah pada suatu daerah atau wilayah. Indeks dominasi berbanding terbalik dengan indeks keragaman semakin tinggi indeks dominasi maka indeks keanekaragaman jenis akan semakin kecil, begitu pula sebaliknya. Suatu jenis jamur ektomikoriza dinilai dominan bila nilai indeks dominasinya lebih tinggi daripada jamur ektomikoriza yang lainnya.

\section{HASIL DAN PEMBAHASAN}

\section{Jenis-Jenis Jamur Ektomikoriza Pada Tegakan Hutan Jati}

Berdasarkan data hasil pengamatan dan identifikasi di lapangan pada tegakan hutan jati di Kampung Wailola ditemukan 16 jenis jamur ektomikoriza dengan jumlah 


\section{Median Volume 11 Nomor 1 Bulan Februari 2019}

Doi http://doi.org/md.v11i1.461

seluruhnya ada 203 individu. Data jenis dan famili ektomikoriza dapat dilihat pada table 1 .

Tabel 1. Jenis dan Famili Jamur Ektomikoriza Pada 15 Plot Pengamatan

\begin{tabular}{|c|c|c|c|c|}
\hline No & $\begin{array}{c}\text { Jenis Jamur } \\
\text { Ektomikoriza }\end{array}$ & Famili & $\begin{array}{c}\text { Jumlah } \\
\text { Individu }\end{array}$ & Presentase $(\%)$ \\
\hline 1 & Auricularia auricula & Auriculariaceae & 3 & 1,48 \\
\hline 2 & Ganoderma sp & Ganodermataceae & 35 & 17,24 \\
\hline 3 & Aleuria sp & Pyronemateceae & 34 & 16,75 \\
\hline 4 & Agrocybe sp & Strophariaceae & 10 & 4,93 \\
\hline 5 & Coprinus sp & Agaricaceae & 3 & 1.48 \\
\hline 6 & Armilaria mellea & Physacriaceae & 11 & 5,42 \\
\hline 7 & Lepiota sp. & Agaricaceae & 3 & 1,48 \\
\hline 8 & Ganorderma $s p^{l}$ & Ganodermataceae & 27 & 13,30 \\
\hline 9 & Schizophyllum commune & Schizophyllaceae & 22 & 10,84 \\
\hline 10 & Tremetes sp. & Polyporaceae & 17 & 8.37 \\
\hline 11 & Amanita verna & Amanitaceae & 3 & 1.48 \\
\hline 12 & Agrocybe sp $p^{l}$ & Strophariaceae & 6 & 2,95 \\
\hline 13 & Polyporus brumalis & Polyporaceae & 12 & 5,91 \\
\hline 14 & Cortinarius $s p$ & Cortinariaceae & 8 & 3,94 \\
\hline 15 & Amanita phallloides & Amanitaceae & 6 & 2,95 \\
\hline 16 & Polyporus arcularius & Polyporaceae & 3 & 1,48 \\
\hline \multicolumn{3}{|c|}{ Total Individu } & 203 & 100 \\
\hline
\end{tabular}

Berdasarkan tabel 1, bahwa jamur ektomikoriza yang ditemukan pada tegakan hutan jati ada 10 famili dengan 16 jenis dimana jenis terbanyak adalah dari family Polyporaceae ada tiga jenis, kedua dari famili Ganodermataceae, Strophariaceae, Agaricaceae, dan Amanitaceae masing-masing 2 jenis dan selanjutnya dari family Auriculariaceae, Pyronemateceae, Physacriaceae, Schizophyllaceae, dan Cortinariaceae masing-masing 1 jenis. Hal ini menunjukkan bahwa pada tegakan hutan jati (family Lamiaceae) memiliki variasi jenis jamur ektomikoriza lebih kecil dibandingkan pada tegakan Dipterocarpaceae dan hutan sekunder, ini sesuai dengan penelitian Noor dan Saridan (2013) pada hutan Taman Nasional Tanjung Puting diperoleh 23 genus, 56 jenis dengan 414 individu dan di Taman Nasional Sebangau jumlah fungi makro diperoleh 13 genus, 33 jenis dengan 296 individu. Didukung pula oleh penelitian Suharno, dkk (2014) pada Distrik Warmare Manokwari sejumlah 30 jenis.

\section{Keanekaragaman, Kemerataan dan Dominasi Jenis Jamur Ektomikoriza}

Untuk menilai tingkat penguasaan jenis, variasi jenis dan kemerataan jenis ektomikoriza maka dilakukan analisis dengan pendekatan indeks keanekaragaman, kemerataan jenis dan dominasi. Hasil analisis terhadap indeks keanekaragaman jenis, kemerataan jenis dan dominasi jenis jamur ektomikoriza pada hutan tegakan jati di Kampung Wailola disajikan pada gambar 1. 


\section{Median Volume 11 Nomor 1 Bulan Februari 2019}

Doi http://doi.org/md.v11i1.461

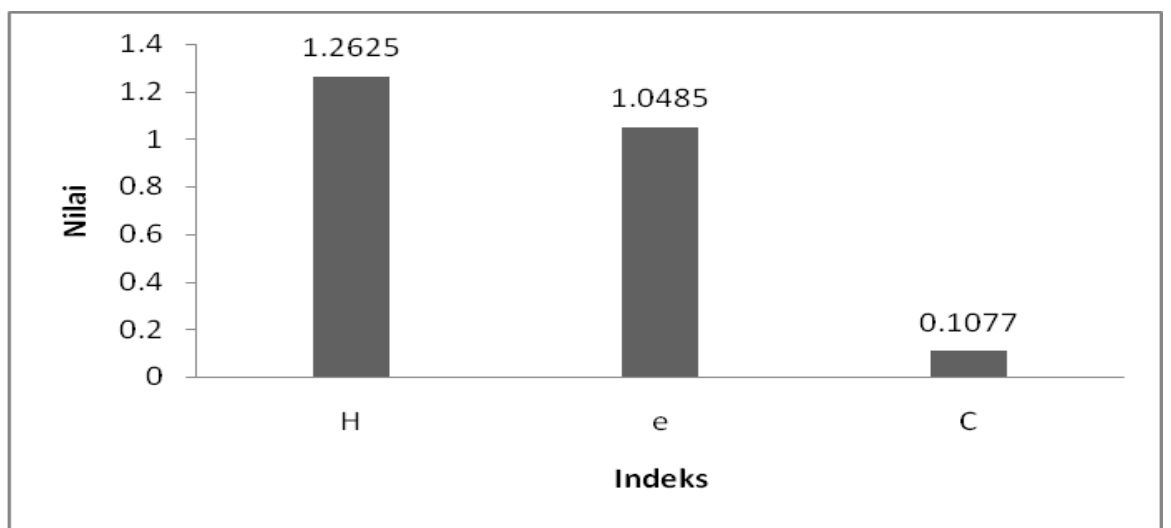

Gambar 1. Indeks Keanekaragaman (H), Kemerataan(e) dan Dominasi (C) Jenis Jamur Ektomikoriza pada Tegakan Hutan Jati (dari Tabel 2. Lampiran)

Berdasarkan pada gambar 1, hasil nilai indeks keanekaragaman jenis ektomikoriza pada tegakan hutan jati adalah tinggi yaitu 1,2625. Wahyuni (2002), menyatakan bahwa kekayaan jenis adalah suatu indikator keanekaragaman yang dipengaruhi oleh beberapa jumlah jenis dan individu fungi makro pada setiap plot pengamatan. Lebih lanjut keberadaan jamur ektomikoriza juga sangat dipengaruhi oleh kondisi habitatnya (Brearley, 2006; Diagne $d k k, 2013$ ). Menurut Odum (1996) dalam Indriyanto (2006), bahwa semakin banyak jumlah spesies, maka semakin tinggi keanekaragamannya. Sebaliknya bila nilainya kecil maka komunitas tersebut didominasi oleh satu jenis atau sedikit jenis. Keanekaragaman jenis juga dipengaruhi oleh pembagian individu dalam tiap jenisnya, tetapi bila penyebaran individu tidak merata maka keanekaragaman jenis dinilai rendah. Tingkat keanekaragaman hayati menunjukkan tingkat kestabilan suatu komunitas hutan. Semakin tinggi tingkat keanekaragaman tersebut maka makin tinggi pula tingkat kestabilan suatu komunitas. Keanekaragaman jenis di dalam dan di antara berbagai komunitas melibatkan 3 komponen yaitu ruang, waktu dan makanan (Indrawan dkk., 2007).

Indeks kemerataan jenis jamur ektomikoriza pada tegakan hutan jati adalah tinggi (1,0485). Menurut Santosa (1995) dalam Sinery (2010), indeks kemerataan jenis menunjukkan ukuran proporsi individu setiap jenis pada suatu komunitas. Bila setiap jenis memiliki jumlah individu yang sama maka komunitas tersebut memiliki indeks kemerataan jenis maksimum.

Hal ini bahwa pada hutan tersebut jenis-jenis jamur ektomikoriza tidak ada yang mendominasi kawasan hutan tersebut. Kisaran indeks dominasi berada pada skala 0 sampai 1 . Semakin mendekati 0 berarti tidak ada komunitas yang mendominasi dalam suatu komunitas. Hal ini menunjukkan adanya keanekaragaman komunitas yang tinggi. Sebaliknya ketika mendekati nilai 1 , berarti ada 1 atau lebih jenis yang mendominasi dalam komunitas tersebut. Ini sering terjadi pada lingkungan yang ekstrem akibat polusi atau lingkungan terganggu.

\section{Habitat Jamur Ektomikoriza}

Berdasarkan hasil identifikasi yang diperoleh di lapangan bahwa jenis-jenis jamur ektomikoriza pada tegakan hutan jati ada yang bersifat epifit (menempel pada bagian batang pohon yang masih hidup) dan saprofit (tumbuh pada tanah maupun batang pohon yang sudah mati atau lapuk). Habitat jamur ektomikoriza disajikan pada tabel 2. 


\section{Median Volume 11 Nomor 1 Bulan Februari 2019}

Doi http://doi.org/md.v11i1.461

Tabel 2. Jumlah dan Presentase Jamur Ektomikoriza Berdasarkan Habitat

\begin{tabular}{cccc}
\hline No & Habitat & Jumlah Jenis & Presentase (\%) \\
\hline 1 & Saprofit & 13 & 81,25 \\
2 & Epifit & 3 & 18,75 \\
\hline & Jumlah & 16 & 100 \\
\hline
\end{tabular}

Berdasarkan pada tabel di atas bahwa dari dua habitat jenis jamur yang termasuk kedalam habitat saprofit mempunyai jumlah jenis dan presentase yang lebih tinggi yaitu sebanyak 13 jenis $(81,25 \%)$ dibandingkan habitat epifit 3 jenis $(18,75 \%)$. Untuk mengetahui ada tidaknya asosiasi antara jamur dengan tanaman inang tertentu dapat dilakukan dengan cara mengidentifikasi jenis jamurnya. Untuk jamur ektomikoriza, metode yang paling meyakinkan adalah dengan menelusuri mikoriza secara langsung dari badan buah Hasil eksplorasi di lapangan bahwa umumnya tubuh buah jamur ektomikoriza ditemukan tumbuh dekat permukaan tanah dan seresah. Radius ditemukannya tubuh buah jamur ektomikoriza dari batang pohon inang ber-variasi dari 0,5-6,1 m. Smith dan Read (2008) dalam Karmilasanti \& Maharani (2016) mengemukakan pula bahwa ektomikoriza banyak dijumpai di alam berasosiasi dengan berbagai pohon tropis baik Dipterocarpaceae maupun Non Dipterocarpaceae.

\section{KESIMPULAN}

Berdasarkan hasil penelitian di lapangan tentang Identifikasi dan Keanekaragaman Jenis Jamur Ektomikoriza Pada Hutan Jati di Seram Bagian Timur adalah sebagai berikut:

1. Jenis jamur ektomikoriza yang terdapat pada tegakan hutan jati di Kampung Wailola di Seram Bagian Timur ditemukan 10 famili dengan 16 jenis jamur ektomikoriza dan jumlah seluruhnya ada 203 individu dimana jenis terbanyak adalah dari famili Polyporaceae ada tiga jenis, kedua dari famili Ganodermataceae, Strophariaceae, Agaricaceae, dan Amanitaceae masing-masing 2 jenis dan selanjutnya dari family Auriculariaceae, Pyronemateceae, Physacriaceae, Schizophyllaceae, dan Cortinariaceae masing-masing 1 jenis.

2. Nilai indeks keanekaragaman dan kemerataan jenis jamur ektomikoriza pada tegakan hutan jati adalah tinggi. Untuk nilai keanekaragaman jenis adalah 1,2625 dan indeks kemerataan jenis yaitu 1,0485. Sedangkan nilai indeks dominasi jenis jamur ektomikoriza pada tegakan hutan jati adalah rendah $(0,1077)$..

3. Habitat jamur ektomikoriza pada tegakan hutan jati yaitu saprofit dan epifit. Saprofit mempunyai jumlah jenis dan presentase yang lebih tinggi sebanyak 13 jenis $(81,25$ $\%)$ dan habitat epifit 3 jenis $(18,75 \%)$.

\section{DAFTAR PUSTAKA}

Amisah . 2012. Jenis Jamur ektomikoriza di wilayah Kalimantan Timur Bukit Soeharto, Wanariset Samboja dan areal ITCI.

Brearly. 2006. Keanekaragaman Jamur Ektomikoriza Pada Ekosistem Hutan. Ejournal.forda mof.org. Di akses 3 Juli 2018.

Darwo, dan Sugiarti. 2008. Beberapa Jenis Cendawan Ektomikoriza di Kawasan Hutan Sipirok, Tongkoh, dan Aek Nauli Sumatera Utara. Jornal Penelitian Hutan dan Konservasi Alam Vol V No.2:157-173,2008. 


\section{Median Volume 11 Nomor 1 Bulan Februari 2019}

Doi http://doi.org/md.v11i1.461

Diagne. 2013. Keanekaragaman Jamur Ektomikoriza Pada Ekosistem Hutan Dipterokarpa. Ejournal.forda mof.org. Di akses 3 Juli 2018.

Dighton. 2016. Jumlah Jenis Jamur Ektomikoriza di KHDTK. Labanan. Ejournal. Forda.mof. org. Di akses 3 Juli 2018.

Dwidjoseputro, D. 2003. Dasar-dasar Mikrobiologi. Djambatan, Jakarta. 214 h

Gandjar, I.; W. Sjamsuridzal dan A. Oetari. 2006. Mikologi Dasar dan Terapan. Yayasan Obor Indonesia, Jakarta, $238 \mathrm{~h}$.

Husna, Faisal. D.T, Mahfudz. 2007. Aplikasi Mikoriza Untuk Memacu Pertumbuhan Jati di Muna. Info Teknis Vol. 5. No.1. Balai Besar Penelitian Bioteknologi dan Pemuliaan Tanaman Hutan.

Indrawan, M; R.B Primack dan J. Supriatna. 2007. Biologi Konservasi. Yayasan Obor Indonesia, Jakarta.

Indriyanto. 2006. Ekologi Hutan. Bumi Aksara, Jakarta.

Kandari, Arif, Amalia, Kasim. Analisis Keberadaan Dan Indeks Keragaman Cendawan Mikoriza Arbuskula (Fma) (Kalappia Celebica Kosterm) Pada Dua Lingkungan Tumbuh Yang Berbeda Di Kabupaten Kolaka Di Areal Rhizosfer Kalapi. Ecogreen Vol. 2 No. 1 April 2016 Halaman 21 - 30 Issn 2407 - 9049.

Karmilasanti \& Maharani. 2016 . Keanekaragaman Jenis Jamur Ektomikoriza Pada Ekosistem Hutan Dipterokarpa Di Khdtk Labanan, Berau, Kalimantan Timur. JURNAL Penelitian Ekosistem Dipterokarpa Vol. 2 No. 2, Desember 2016 : 57 66.

Mardji, D. dan Ch. Soeyamto. 1999. Jenis-jenis Jamur dari Labanan Kabupaten Berau Kalimantan Timur. Berau Forest Management Project, Samarinda. 53 h.

Noor. 2010. Geomorfology. https//www.scrids.com. document. Diakses 2 Juli 2018.

Noor Dan Saridan. 2013.Keanekaragaman Fungi Makro Pada Tegakan Benih Dipterocarpaceae Di Taman Nasional Tanjung Putting Dan Taman Nasional Sebangau Kalimantan Tengah. JURNAL Penelitian Dipterokarpa Vol. 7 No. 1, Juni 2013: 53-62 ISSN: 1978-8746.

Nuhamara. 2009. Peranan Mikoriza Untuk Reklamasi Lahan Kritis.http//tumoutou.net/702_07134/naswir.htm. Di akses 2 Juli 2018.

Odum, P. 1993. Dasar-dasar Ekologi. Edisi Ketiga. Gadjah Mada Univ. Press, Yogyakarta.

Suharno, Irawan, C., Qomariah, E. N., Putri, I. A., \& Sufaati, S. (2014). Keragaman Makrofungi di Distrik Warmare Kabupaten Manokwari , Papua Barat. Jurnal Biologi Papua, 6(1), 38-46.

Sinery, A. 2010. Populasi Kuskus di Cagar Alam Pegunungan Arfak Kabupaten Manokwari Provinsi Papua Barat. Jurnal Agrifor IX (2): 78-88.

Soegianto, A. 1994. Ekologi Kuantitatif Metode Analisis Populasi dan Komunitas. Penerbit Usaha Nasional, Jakarta.

Wahyuni. 2002. Studi Keanekaragaman dan Penyebaran Jenis Burung Untuk Pengembangan Rekreasi Alam di Kebun Raya Samarinda Lempake, Provinsi KalimantanTimur. Tesis program Pascasarjana Universitas Mulawarman Samarinda. Hal. 123. 